\title{
Androgenic alopecia: an entity to consider in adolescence
}

\author{
Marlene Rodrigues, ${ }^{1}$ Inês Antunes, ${ }^{2}$ Sara Magalhães, ${ }^{2}$ Nelson Pereira ${ }^{2}$
}

'Hospital de Braga, Braga, Portugal

${ }^{2}$ Family Physicians, USF Ponte, Guimarães, Portugal

Correspondence to Dr Marlene Rodrigues, rodrigues.f.marlene@gmail.com

Accepted 4 July 2017
CrossMark

To cite: Rodrigues $M$, Antunes I, Magalhães $S$, et al. BMJ Case Rep Published Online First: [please include Day Month Year]. doi:10.1136/bcr-2017220679

\section{DESCRIPTION}

A 15 -year-old healthy adolescent girl went to her physician consultation because she was preoccupied with progressive thinning of her hair since 11 years old. In the last year, she noticed an aggravation, with an excessive hair loss. She does not have hirsutism, acne, asthenia, menstrual irregularities or weight variations. In her family history, she reported that her mother had 'excessive hair loss after pregnancy' and her maternal aunt has alopecia of unknown aetiology. At physical examination it was observed diffuse reduction of capillary thickness and density at the frontal scalp area (figure 1) and vertex (figure 2). Rare black dots were present and the pull test was negative. The analytical study including blood count, iron kinetics, thyroid function and hormonal study had no alterations. The pelvic and adrenal gland's ultrasound were normal. At dermatology consultation, scalp biopsy revealed findings compatible with androgenic alopecia. She started treatment with oral contraceptive, oral spironolactone and topical minoxidil solution, with improvement of alopecia areas.

Androgenic alopecia is the most prevalent form of alopecia in adulthood, but little is known about its prevalence, characteristics and natural history in paediatric population. ${ }^{1}$ In children and adolescents with genetic predisposition, the first signs of androgenic alopecia may arise with increased levels of androgens at puberty, but the presence of androgenic alopecia in children with prepubertal testosterone levels and women with

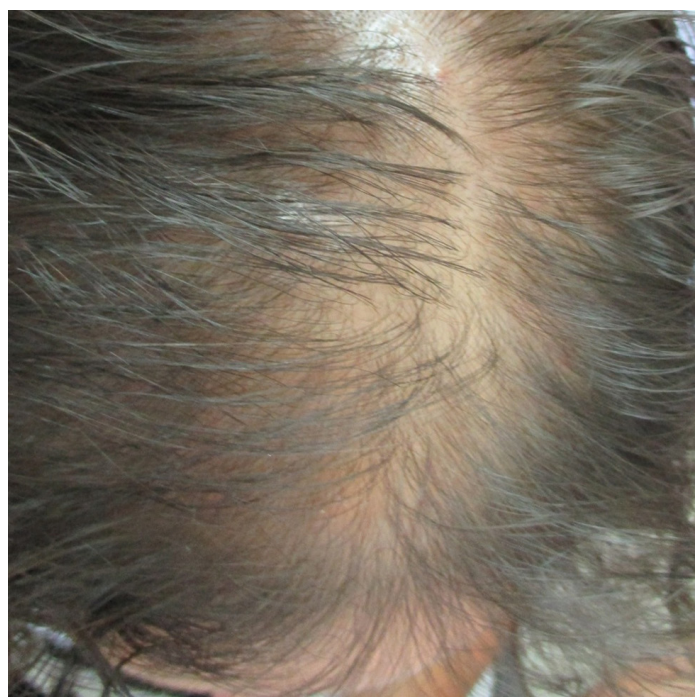

Figure 1 Adolescent's scalp frontal area.

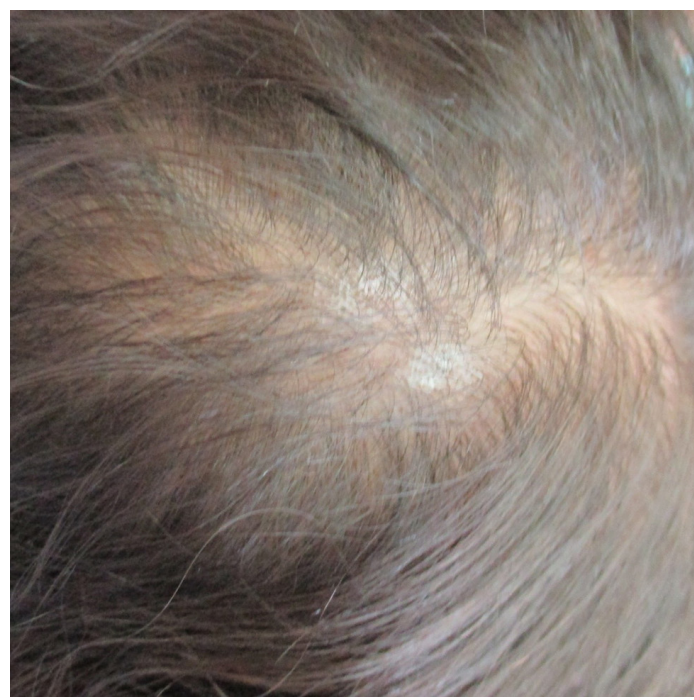

Figure 2 Adolescent's scalp vertex.

Learning points

- Androgenic alopecia may begin in adolescence, and its presentation is varied. In females, it is often manifested by a progressive hair weakening that may or may not be associated with hyperandrogenism.

- Usually, androgenic alopecia is a clinical diagnosis, but depending on the history and clinical evaluation, and especially in the paediatric age, additional diagnostic tests may be required.

- Alopecia may not have direct physical consequences for health but, certainly, it has an important psychosocial impact, especially in adolescence.

normal hormonal profiles, like in the case we reported, suggests that in some cases the 'female pattern hair loss' may not be androgen dependent or that adrenal androgens may have direct action. $^{23}$

Contributors MR has substantial contributions to the conception of the work, acquisition, analysis and interpretation of data; participated in writing the article, in revision and final approval of the version. IA has substantial contributions to acquisition data, patient treatment and follow-up; received informed content from the patient; revision and final approval of the version. SM has substantial contributions to acquisition data, patient treatment and follow-up; revising and final approval of the article. NP has substantial contributions to the conception of the work; acquisition and interpretation of data; treatment and follow-up; revising and final approval of the article. 


\section{Images in...}

\section{Competing interests None declared.}

Patient consent Obtained from guardian.

Provenance and peer review Not commissioned; externally peer reviewed.

(c) BMJ Publishing Group Ltd (unless otherwise stated in the text of the article) 2017. All rights reserved. No commercial use is permitted unless otherwise expressly granted.

\section{REFERENCES}

1 Gordon KA, Tosti A. Alopecia: evaluation and treatment. Clin Cosmet Investig Dermatol 2011:4:101-6.

2 Vujovic A, Del Marmol V. The female pattern hair loss: review of etiopathogenesis and diagnosis. Biomed Res Int 2014;2014:1-8.

3 Mounsey AL, Reed SW. Diagnosing and treating hair loss. Am Fam Physician 2009;80:356-62.

Copyright 2017 BMJ Publishing Group. All rights reserved. For permission to reuse any of this content visit http://group.bmj.com/group/rights-licensing/permissions.

BMJ Case Report Fellows may re-use this article for personal use and teaching without any further permission.

Become a Fellow of BMJ Case Reports today and you can:

- Submit as many cases as you like

- Enjoy fast sympathetic peer review and rapid publication of accepted articles

- Access all the published articles

Re-use any of the published material for personal use and teaching without further permission

For information on Institutional Fellowships contact consortiasales@bmjgroup.com

Visit casereports.bmj.com for more articles like this and to become a Fellow 